\title{
Application of Box-Behnken design for optimization of malachite green removal from aqueous solutions by modified barley straw
}

\author{
Ghasemi S.M. ${ }^{1 *}$, Ghaderpoori M. ${ }^{2,3 *}$, Moradi M. ${ }^{4}$, Taghavi M. ${ }^{5}$ and Karimyan K. ${ }^{6}$ \\ ${ }^{1}$ Deputy of Health, Babol University of Medical Sciences, Babol, Iran \\ ${ }^{2}$ Department of Environmental Health Engineering, School of Health and Nutrition, Lorestan University of Medical Sciences, \\ Khorramabad, Iran \\ ${ }^{3}$ Nutritional Health Research Center, Lorestan University of Medical Sciences, Khorramabad, Iran \\ ${ }^{4}$ Master of Science, Department of Health Public, Kermanshah University of Medical Sciences, Kermanshah, Iran \\ ${ }^{5}$ Department of Environmental Health Engineering, School of Public Health, Social Development \& Health Promotion Research Center, \\ Gonabad University of Medical Sciences, Gonabad, Iran \\ ${ }^{6}$ Environmental Health Research Center, Kurdistan University of Medical Sciences, Sanandaj, Iran \\ Received: 22/02/2019, Accepted: 03/08/2020, Available online: 23/09/2020 \\ *to whom all correspondence should be addressed: e-mail: ghasemimehdi61@gmail.com; mghaderpoori@gmail.com \\ https://doi.org/10.30955/gnj.003089
}

\section{Graphical abstract}

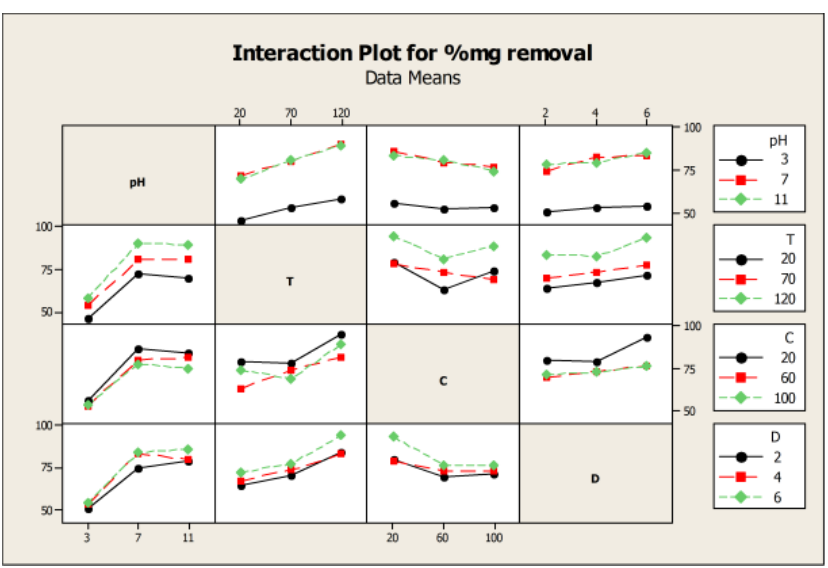

\begin{abstract}
Untreated wastewater can have important effects on the environment and human. The work aimed to evaluate the effectiveness of modified barley straw to remove Malachite Green (MG) from industrial wastewater. Studied variables were $\mathrm{pH}$, contact time, initial malachite green concentration, and adsorbent dosage. Box-Behnken design method was used for modelling the process of adsorption. The results of the analysis of variance showed that there is a significance relative among process parameters. The high value of $R^{2}(0.9753)$ indicated that there was a high correlation between the predicted and experimental values. The removal efficiency of malachite green increased by increasing of modified barley straw dosage, $\mathrm{pH}$ and contact time, and decreasing of color concentration. Remove the color was better in alkaline conditions and the best $\mathrm{pH}$ was equal to 9.5. The optimum contact time to remove was $120 \mathrm{~min}$. The findings of this study showed that the Box-Behnken model can efficiently
\end{abstract}

optimize the malachite green adsorption onto modified barley straw from aqueous solutions.

Keywords: Adsorption, barley straw, Box-Behnken design, malachite green.

\section{Introduction}

Discharge of color materials to the surrounding environment have harmful effects (Demirbas, 2009). It is estimated that there are more than ten thousands of various chemical dye (Golmohammadi et al., 2016; Kamarehie et al., 2018). Annually, more than 700000 tons of dye produced worldwide (Demirbas, 2009; Massoudinejad et al., 2015; Saleh et al., 2018). The results of various studies show that during the manufacturing and processing of dye, almost $10 \%$ lost and this amount lost 20 percent goes to the industrial system (Chakraborty et al., 2011). The presence color can be seen in very low concentrations (Even lower than $1 \mathrm{mg} \mathrm{L}^{-1}$ ) and have adverse effects on water quality (Rafatullah et al., 2010). The harmful effects of Discharge of untreated effluent/wastewater on the environment include toxicity of aquatic lives, reduce light transmission, thus reducing photosynthesis (Ghaderpoori et al., 2016; Gözmen et al., 2009). Health effects on the human being include vomiting, jaundice, shock, quadriplegia, cyanosis, allergy, skin irritation, dermatitis, mutations and tissue necrosis, and finally cancer and death (Belala et al., 2011; Noroozi et al., 2007). Based on the solubility and insolubility, color can be classified. Soluble dyes include acidic, basic, metal, mordant, complex, direct, and reactive. Insoluble dyes include sulfur, azoic, and disperse (Gupta and Suhas, 2009). In one direction, colors are divided into three groups: cationic, anionic, and nonionic (Salleh et al., 2011). Anionic colors have less toxicity than cationic colors (El-Sayed, 2011). N-methylated diamino triphenylmethane dye (also known as Malachite Green, MG) is a cationic color. It has a 
high solubility in water. Its industrial applications are coloring in cotton, paper, leather, wool and silk (Saha et al., 2010; Banerjee et al., 2016; Jiang et al., 2017). So far, various methods have been used to remove them from the environment. These methods include flocculation and precipitation, ion exchange, membrane filtration, irradiation and ozonation, and electrochemical destruction. However, the methods have disadvantages such as High cost, high sludge production, and production of by-products. Among the used processes, the adsorption is one of the most important processes that can be considered seriously. Advantages of the adsorption process are: the lower cost of operation, the need for simple force, the recovery of used adsorbent. In the adsorption process, various adsorbents can be used. Each adsorbent has advantages and disadvantages. Activated carbon is a suitable absorbent but its initial cost is high. Also, due to economic considerations, it cannot be used on a large scale for treatment of large quantity of effluents. In recent years, the use of cheap and low-cost absorbents has been accelerating (Ahmad, 2009; Akar et al., 2009; Karim et al., 2009; Sharma et al., 2012). One of the materials that can be used as a low-cost absorbent is agriculture waste. The ingredients of this waste are lignin, cellulose (as the main combination), aldehydes, alcohols, carboxylic, ketones, phenolic, and ether groups (as functional groups). The presence of various functional groups in these adsorbents can effectively affect the adsorption of pollutants (Demirbas, 2008). So far, various agriculture waste have been used such as rice husk, wheat straw, sugarcane bagasse, corncob shreds, maize cob, barley husk, almond shell, banana pith, hazelnut shell, apricot stone, orange peel, walnut shell, tree fern, olive pomace, saw dust, and wood shaving (Sharma et al., 2011). Studies have shown that modifying agricultural adsorbents with organic substances such as citric acid increases the Carboxyl group at the adsorbent surface and thereby increases the removal of pollutants (Zhu et al., 2008). So, the purpose of this study was to optimize MG adsorption using citric acid modified barley straw from aqueous solutions. BoxBehnken design (BBD) was used to develop a mathematical correlation among MG adsorption and independent variables.

\section{Materials and methods}

\subsection{Materials and apparatus}

Malachite green was obtained from Alvan sabet Company. Its molecular weight is $365 \mathrm{~g} \mathrm{~mol}^{-1}$. MG chemical formula is $\mathrm{C}_{23} \mathrm{H}_{25} \mathrm{~N}_{2} \mathrm{Cl}$. The chemical structure of MG is shown in Figure 1.

\subsection{Preparation of adsorbent}

At first, ground barley straw mixed with $0.6 \mathrm{~mol} \mathrm{~L}^{-1}$ of citric acid at the ratio of 1:12 (straw/acid, w/v) and stirred for 30 min at $20^{\circ} \mathrm{C}$. The acid straw slurries placed in a stainless steel tray and dried at $50^{\circ} \mathrm{C}$ for $24 \mathrm{~h}$ in a forced-air oven. Then, the thermochemical esterification between acid and straw was proceeded by raising the oven temperature to $120^{\circ} \mathrm{C}$ for $90 \mathrm{~min}$. After cooling at lab temperature, the barley straw was washed with distilled water until reaching natural $\mathrm{pH}$ and filtered. After filtration, barley straw was suspended in $0.1 \mathrm{~mol} \mathrm{~L}^{-1}$ of $\mathrm{NaOH}$ solution at a suitable ratio and stirred for $60 \mathrm{~min}$, followed by washing thoroughly with distilled water to remove residual alkali. Finally, modified adsorbent dried at $50^{\circ} \mathrm{C}$ for $24 \mathrm{~h}$ and preserved in a desiccator for next (Han et al., 2010). The surface morphology of the adsorbent was characterized with Scanning electron microscope (KYKY,EM3200).

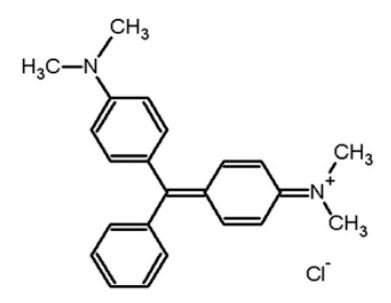

Figure 1. Chemical structure of Malachite Green

\subsection{Adsorption study}

All experiments were performed in the batch conditions. The variables such as the initial concentration of MG, $\mathrm{pH}$ and modified barley straw dosage were investigated. First, $\mathrm{pH}$ was adjusted using $\mathrm{HCl}(0.1 \mathrm{~N})$ and $\mathrm{NaOH}(0.1 \mathrm{~N})$. Then, the modified barley straw was added to the MG solution. The MG solution was stirred at a constant speed of 150 $\mathrm{rpm}$. To separate the absorbent solution, a membrane filter $0.45 \mu \mathrm{m}$ was used. The final concentration of MG was measured using a spectrophotometer (UV-VIS) at a wavelength of $618 \mathrm{~nm}$ (Chowdhury et al., 2011; Safronov, Strelov et al., 2012). The removal of dye (\%) was calculated using Eq. 1 (Ghasemi et al., 2017):

$$
R, \%=\left(C_{0}-C_{e}\right) / C_{0} \times 100
$$

Where, $\mathrm{C}_{0}$ and $\mathrm{C}_{\mathrm{e}}$ are the initial and final concentrations of MG $\left(\mathrm{mg} \mathrm{l}^{-1}\right)$, respectively.

\subsection{Response surface methodology and experimental design}

RSM is a statistical technique for design of experiments. The software has different methods of modelling. The main advantage of this software is to reduce the number of experiments (Zainal et al., 2013; Massoudinejad et al., 2016). Among different approaches to modelling, usually, three methods central composite design (CCD), BoxBehnken design (BBD), and Doehlert matrix (DM) is most recommended (Zolgharnein et al., 2013). In the current study, Box-Behnken design was used to determine the relationship between independent and dependent variables in MG adsorption. Design of experiments (four variables at three levels) was done using Minitab 16 software. The independent variables of input to the software were: initial MG concentration, adsorbent dosage, $\mathrm{pH}$, and contact time. Table 1 shows the input variables to the model. According to the formula $\mathrm{N}=2 \mathrm{k}(\mathrm{k}-1)+\mathrm{C}_{0}, \mathrm{k}$ is the number of variables and $\mathrm{C}_{0}$ is the number of center points (Zolgharnein et al., 2013), the total number of the experiment was 27 . The actual experimental design matrix shows in Table 2. 
Table 1. Experimental range and levels of independent process variables

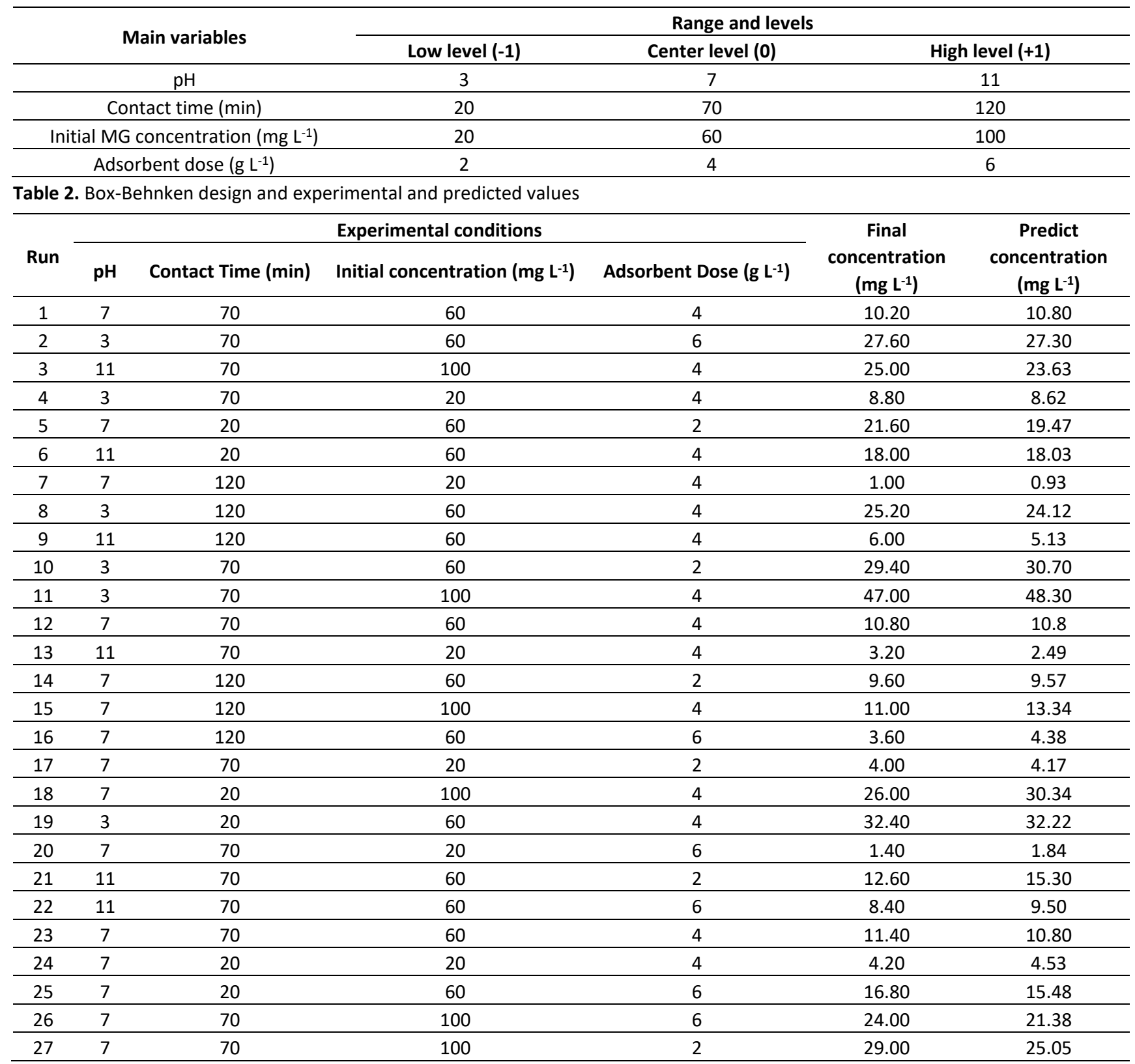

For RSM, the most commonly used second-order polynomial equation developed to fit the experimental data and determine the relevant model terms can be written as follow (Eq. 2) (Olmez, 2009):

$$
Y, \%=\beta_{0}+\Sigma \beta_{i} X_{i}+\Sigma \beta_{i i} X_{i}^{2}+\Sigma \beta_{i j} X_{i} X_{j}^{2}
$$

Where, $\mathrm{Y}$ is the percentage of adsorbed $\mathrm{MG}, \beta_{0}$ is the constant coefficient. $\beta_{i}, \beta_{i i}$ and $\beta_{i j}$ are the effect of firstorder, second-order, and interaction. $X_{i}$ and $X_{j}$ are the independent variables (Olmez, 2009). The goodness of fit for this study was calculated using the coefficient of determination $\left(R^{2}\right)$ and the analysis of variance. A p-value of less than 0.05 indicates model terms are significant.

\subsection{Adsorption kinetics and isotherms}

Common isotherms and kinetic models were studied to assign the behavior of MG adsorption onto modified barley straw. The model of adsorption isotherms are studied such as Langmuir (Eq. 3), Fraundlich (Eq. 4), and Temkin (Eq. 5) in order to assign the relationship between equilibrium concentration and equilibrium capacity( Kamarehie et al., 2018). Adsorption kinetics were investigated to forecast the reaction rate of $M G$ adsorption and adsorption mechanisms on the new adsorbent. In present work, kinetic models of pseudo-first-order (Eq. 6), pseudosecond-order (Eq. 7), Intra particle diffusion model (Eq. 8) and Elovich (Eq. 9), were studied to define the kinetics of MG adsorption onto the modified barley straw (Ghasemi et al., 2016; Mohsenibandpei et al., 2016).

$$
\left.C_{e} / q_{e}=\left[1 /\left(k_{L} \cdot q_{m}\right)\right]+\left[\left(1 / q_{m}\right) \cdot C_{e}\right)\right]
$$

$\log q_{e}=1 / n . \log C_{e}+\log K_{F}$

$\mathrm{q}_{\mathrm{e}}=\mathrm{B} 1 \ln \left(\mathrm{k}_{\mathrm{t}}\right)+\mathrm{B} 1 \ln \left(\mathrm{C}_{\mathrm{e}}\right)$

$\log \left(q_{e}-q_{t}\right)=\log q_{e}-\left(k_{1} \cdot t / 2.303\right)$ 


$$
\begin{aligned}
& t / q_{t}=1 /\left(k_{2} \cdot q_{e}{ }^{2}\right)+\left[\left(1 / q_{e}\right) \cdot t\right] \\
& q_{t}=k_{i} \cdot t^{0.5}+c \\
& q_{t}=1 / \beta \ln (\alpha \beta)+1 / \beta \ln t
\end{aligned}
$$

\section{Results and discussion}

\subsection{Characterization of adsorbent}

Scanning electron microscope (SEM) was used to analyze the surface morphology of crude and modified barley straw. As can be seen in Figure 2, before the acid modification, the straw surface was smooth with fewer holes.
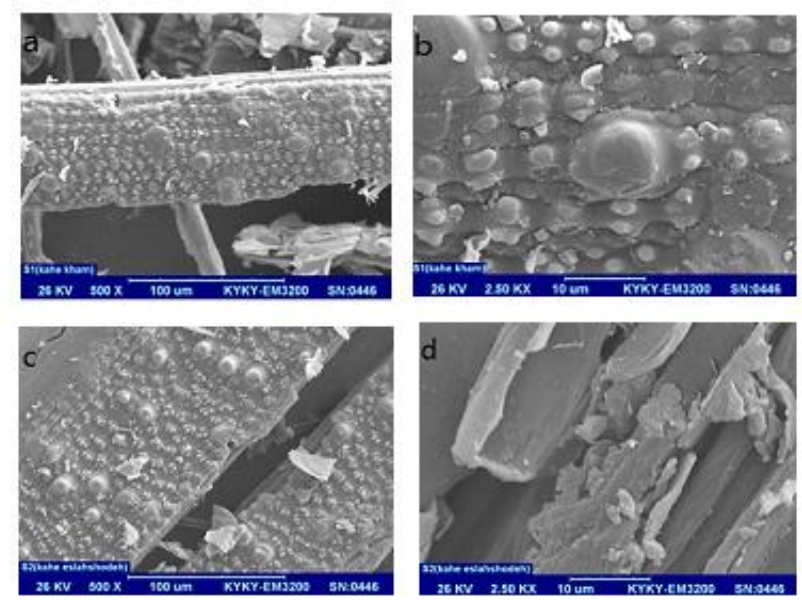

Figure 2. SEM images of the samples ( $a$ and $b$ ) crude barley straw; (c and d) modified barley straw

\subsection{The validation of the response surface model}

Data analysis was done using the Minitab 16 Software. For proper analysis, these assumptions should be considered: (a) The residuals have a normal distribution with zero means, (b) there is constant variance, and (c) the residuals are independent. The results of this part shown in Figure 3. Figure 3-a show normal-probability plots of the residuals from the least-squares fitting. These points are a straight line that confirms the error is close to zero. Figure 3-b show random-scatter plots of the residuals versus the fitted values. This chart shows that do not have any obvious pattern. The predicted results were revealed to be randomly scattered around the zero lines (above and below the $\mathrm{X}$-axis), which supports the adequacy of the proposed model. Figure 3-c show the frequencies of the residuals, and it confirmed that there are no outliers in the data. Finally, Figure 3-d show the ordered residuals oscillate in a random pattern around the zero lines. The residuals appear to be randomly scattered along the zero lines that indicate the error terms do not correlate with each other. Tables 3 and 4 show the results of ANOVA and regression coefficients, respectively. According to Joglekar and May study proposal, square $R\left(\right.$ or $R^{2}$ ) should be at least 0.8 to the goodness of fit of the model (Joglekar and May, 1987). The square $R$ for data obtained 0.97 that was higher than 0.8. According to the software instructions, the difference in adjusted $R^{2}$ and predicted $R^{2}$ should not be greater than 0.2. In this study, adjusted $R^{2}$ and predicted $R^{2}$ were 0.95 and 086 respectively. The lack-of-fit test was designed to determine whether the model is adequate to describe the observed data or whether a more complicated model should be used. Since the P-value for lack of fit in the ANOVA is greater or equal to 0.05 , the model appears to be adequate for the observed data at the $95 \%$ confidence level (Simsek, Özdemir et al., 2013). Besides, the F value for lackof-fit is insignificant ( $p_{\text {value }}=0.07>0.05$ ) thereby confirming the validity of the model. Hence, the response surface model developed in this study for predicting MG removal efficiency was considered to be satisfactory. By ignoring the insignificant terms ( $p_{\text {value }}>0.05$ ) in Table 3 , the model equation (Eq. 10) can be written as:

$$
\begin{aligned}
& \mathrm{Y}=82+13.83 \mathrm{pH}+8.75 \mathrm{~T}-4.08 \mathrm{C}+3.83 \mathrm{D}-14.62(\mathrm{pH}) 2 \\
& \text { (coded units) }
\end{aligned}
$$

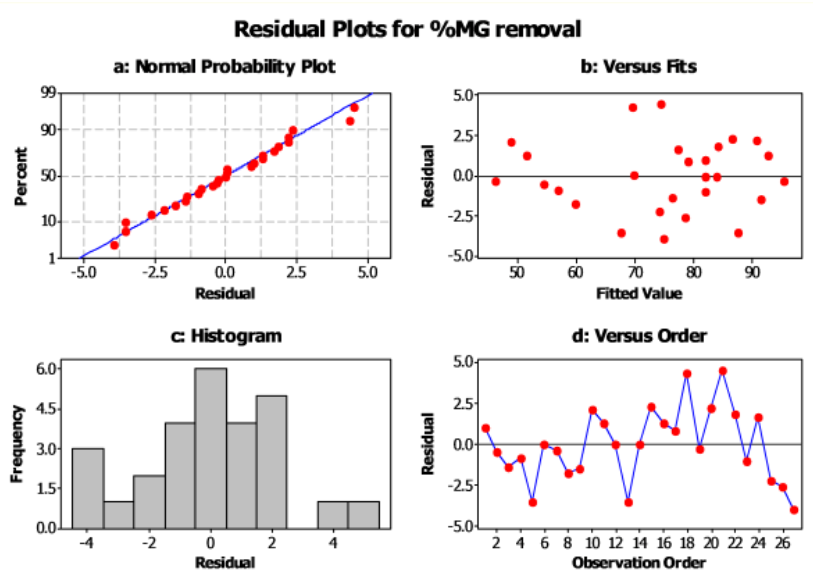

Figure 3. Residual plots for MG adsorption on the modified barley straw

\subsection{The effect of modified absorbent on MG adsorption}

So far, many adsorbents have been modified with agents such as mineral and organic acid solutions (e.g. hydrochloric acid, phosphoric acid, tartaric acid, citric acid, thioglycolic acid), basic solutions (e.g. $\mathrm{NaOH}$ ), etc (Han et al., 2010). Wong et al used modified adsorbent by carboxylic acids like salicylic acid, oxalic acid, tartaric acid, mandelic acid, malic, and nitrilotriacetic acid to remove $\mathrm{Cu}$ (II) and $\mathrm{Pb}$ (II). The findings showed that the adsorption capacity of modified adsorbent for these pollutants has increased (Wong et al., 2003). Zhu et al used tartaric acid modified maize hull (modified by free carboxyl groups) to remove $\mathrm{Cu}$ from aquatic solutions. The final results showed that the adsorption capacity of modified adsorbent for $\mathrm{Cu}$ (II) enhanced (Zhu et al., 2008). In another study, Yang et al used modified pine sawdust by CA to remove $\mathrm{Ni}$ (II), $\mathrm{Cu}$ (II), $\mathrm{Cd}$ (II), Pb (II), and $\mathrm{Zn}$ (II). The results showed that modified

adsorbent enhanced the adsorption of these elements (Yang et al., 2010). In the present study, barley straw adsorbent was modified by citric acid. The modified adsorbent is new and biodegradable. Modification by acid also breaks the covalent bonds among lignocelluloses, 
hydrolyzing hemicelluloses, and depolymerizing lignin thereby increasing the exposure of cellulose which further enhances the adsorption properties of barley straw
(Chakraborty et al., 2013). Modification with CA also can enhance the contact surface between adsorbent and pollutants (Han et al., 2010).

Table 3. Estimated regression coefficients for MG adsorption onto modified barley straw

\begin{tabular}{|c|c|c|c|c|}
\hline Term & Coef. & SE Coef. & $\mathbf{T}$ & $\mathbf{P}_{\text {value }}$ \\
\hline Constant & 82 & 1.88 & 43.61 & 0.000 \\
\hline $\mathrm{pH}$ & 13.83 & 0.94 & 14.72 & 0.000 \\
\hline $\mathrm{T}$ & 8.750 & 0.94 & 9.31 & 0.000 \\
\hline$C$ & -4.08 & 0.94 & -4.34 & 0.001 \\
\hline $\mathrm{D}$ & 3.83 & 0.94 & 4.08 & 0.002 \\
\hline $\mathrm{pH}^{*} \mathrm{pH}$ & -14.62 & 1.41 & -10.37 & 0.000 \\
\hline $\mathrm{T}^{*} \mathrm{~T}$ & -0.50 & 1.41 & -0.35 & 0.729 \\
\hline $\mathrm{C} * \mathrm{C}$ & 0.75 & 1.41 & 0.53 & 0.605 \\
\hline$D^{*} \mathrm{D}$ & -1.8750 & 1.4101 & -1.330 & 0.208 \\
\hline $\mathrm{pH}^{*} \mathrm{~T}$ & 2.0000 & 1.6282 & 1.228 & 0.243 \\
\hline $\mathrm{pH}^{*} \mathrm{C}$ & -1.5000 & 1.6282 & -0.921 & 0.375 \\
\hline $\mathrm{pH}^{*} \mathrm{D}$ & 1.0000 & 1.6282 & 0.614 & 0.551 \\
\hline $\mathrm{T}^{*} \mathrm{C}$ & -0.2500 & 1.6282 & -0.154 & 0.881 \\
\hline$T * D$ & 0.5000 & 1.6282 & 0.307 & 0.764 \\
\hline$C * D$ & -2.0000 & 1.6282 & -1.228 & 0.243 \\
\hline \multicolumn{5}{|c|}{$R^{2}=97.53 \% R^{2}($ Adj. $)=94.66 \% R^{2}($ Pred. $)=85.93 \%$} \\
\hline
\end{tabular}

Table 4. ANOVA table for MG adsorption in the Box-Behnken design

\begin{tabular}{|c|c|c|c|c|c|c|}
\hline Source & DF & Seq SS & Adj SS & Adj MS & F value & P-value \\
\hline Regression & 14 & 5031.42 & 5031.42 & 359.39 & 33.89 & 0.000 \\
\hline Linear & 4 & 3591.50 & 3591.50 & 897.88 & 84.67 & 0.000 \\
\hline $\mathrm{pH}$ & 1 & 2296.33 & 2296.33 & 2296.33 & 216.55 & 0.000 \\
\hline $\mathrm{T}$ & 1 & 918.75 & 918.75 & 918.75 & 86.64 & 0.000 \\
\hline $\mathrm{C}$ & 1 & 200.08 & 200.08 & 200.08 & 18.87 & 0.001 \\
\hline $\mathrm{D}$ & 1 & 176.33 & 176.33 & 176.33 & 16.63 & 0.002 \\
\hline Square & 4 & 1393.67 & 1393.67 & 348.42 & 32.86 & 0.000 \\
\hline $\mathrm{pH}^{*} \mathrm{pH}$ & 1 & 1363.27 & 1140.75 & 1140.75 & 107.58 & 0.000 \\
\hline $\mathrm{T} * \mathrm{~T}$ & 1 & 0.31 & 1.33 & 1.33 & 0.13 & 0.729 \\
\hline $\mathrm{C}^{*} \mathrm{C}$ & 1 & 11.34 & 3 & 3 & 0.28 & 0.605 \\
\hline$D * D$ & 1 & 18.75 & 18.75 & 18.75 & 1.77 & 0.208 \\
\hline Interaction & 6 & 46.25 & 46.25 & 7.71 & 0.73 & 0.637 \\
\hline $\mathrm{pH}^{*} \mathrm{~T}$ & 1 & 16 & 16 & 16 & 1.51 & 0.243 \\
\hline $\mathrm{pH}^{*} \mathrm{C}$ & 1 & 9 & 9 & 9 & 0.85 & 0.375 \\
\hline $\mathrm{pH}^{*} \mathrm{D}$ & 1 & 4 & 4 & 4 & 0.38 & 0.551 \\
\hline $\mathrm{T}^{*} \mathrm{C}$ & 1 & 0.25 & 0.25 & 0 & 0.02 & 0.881 \\
\hline$T * D$ & 1 & 1 & 1. & 1 & 0.09 & 0.764 \\
\hline$C * D$ & 1 & 16 & 16 & 16 & 1.51 & 0.243 \\
\hline Residual error & 12 & 127.25 & 127.25 & 10.6 & & \\
\hline Lack-of-Fit & 10 & 125.25 & 125.25 & 12.53 & 12.53 & 0.076 \\
\hline Pure Error & 2 & 2 & 2 & 1 & & \\
\hline Total & 26 & 5158.67 & & & & \\
\hline
\end{tabular}

\subsection{Effect of $p H$ and contact time on $M G$ removal}

The interaction effects of $\mathrm{pH}$ and contact time of MG show in Figure 4 and Figure 6 . The findings showed that with decreasing $\mathrm{pH}$ and contact time, $\mathrm{MG}$ adsorption decreased. The $\mathrm{pH}_{z \mathrm{pc}}$ of modified barley straw is 5.6, thus it is negatively charged at $\mathrm{pH}>\mathrm{pH}_{\mathrm{zpc}}$ and is positively charged at $\mathrm{pH}<\mathrm{pH}_{\mathrm{zpc}}$. On the other hand, MG can show a different cationic $\left(\mathrm{pH}>\mathrm{pK}_{\mathrm{a}}\right)$ or anionic $\left(\mathrm{pH}<\mathrm{pK}_{\mathrm{a}}\right)$ structure due to $\mathrm{pK}$ value $\left(\mathrm{pK}_{\mathrm{a}}=6.9\right)$. Thus, by increasing $\mathrm{pH}$ (alkaline conditions), the electrostatic attraction force between the negative surface of the adsorbent and the cationic dye increases the removal efficiency (Güler et al., 2019). At acidic conditions, carboxyl group becomes a non-ionic form group $\left(-\mathrm{CO}_{2} \mathrm{H}\right)$ that this form is not suitable for adsorption (Gong et al., 2009). The results showed when the contact time increases, MG adsorption improved. According to Rastogi et al. findings, the cause of this increase can be the presence of vacant sites of adsorption onto the modified adsorbent surface (Singh et al., 2005). 


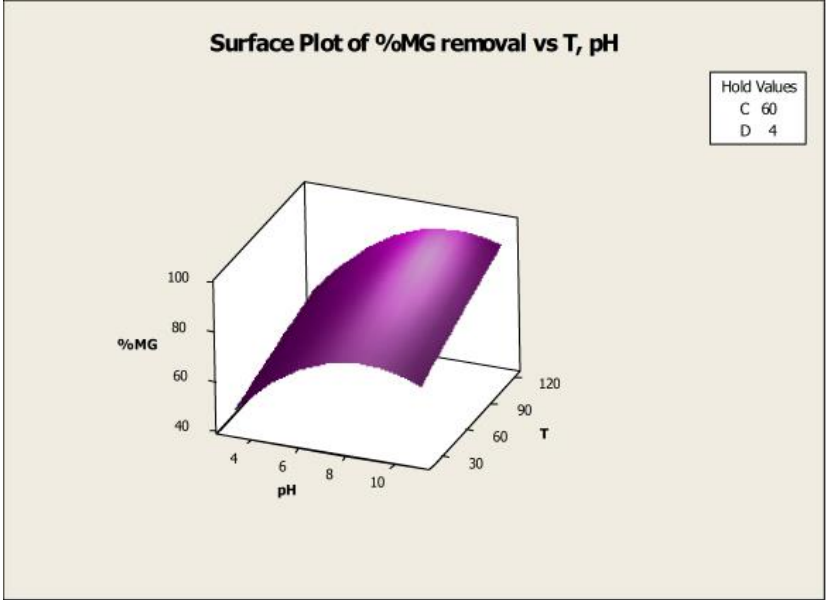

a

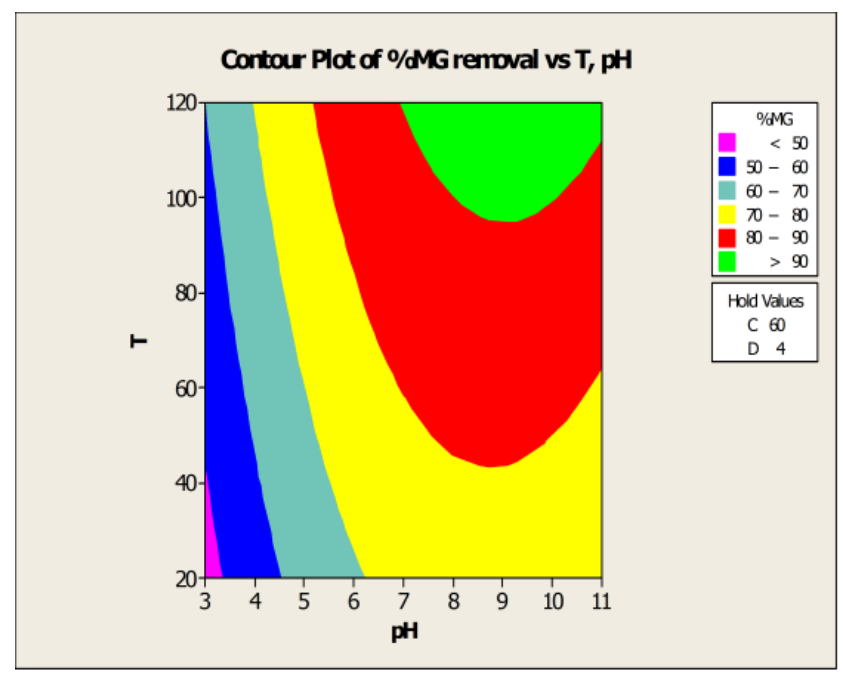

b

Figure 4. Response (a) surface plot and (b) contour plot of the MG removal efficiency (\%) as a function of contact time and $\mathrm{pH}$

3.5. Interaction effects of modified barley straw dosage and MG concentration onto MG adsorption

The interaction effects of adsorbent dosage and initial concentration of MG show in Figure 5 and Figure 6 . The best adsorption of MG is in an adsorbent dose of $6 \mathrm{~g} \mathrm{~L}^{-1}$. One of the reasons for increasing $M G$ adsorption by increasing the adsorbent dose can be because of the increase in the number of adsorption sites. Various studies confirm this issue (Tilaki et al., 2014). By increasing the MG concentration, removal efficiency decreased. This reduction in removal efficiency can be due to the saturation of sorption sites onto modified barley straw (Deniz and Karaman, 2011).

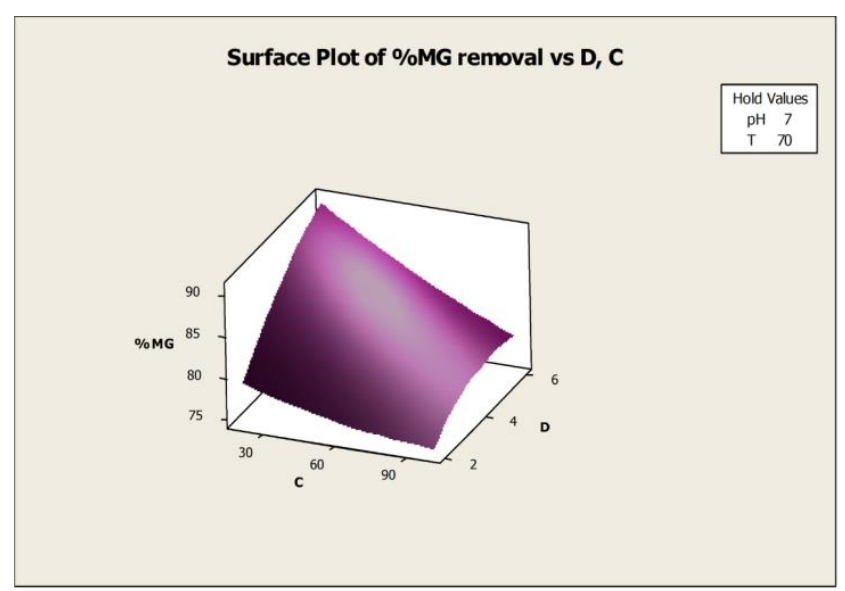

a

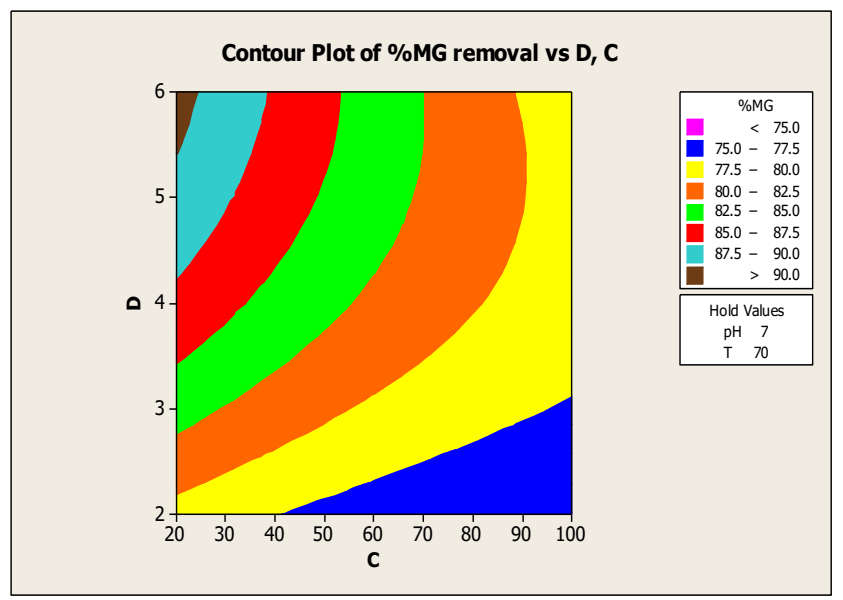

b

Figure. 5. Response (a) surface plot and (b) contour plot of the MG removal efficiency (\%) as a function of adsorbent dosage and MG concentration

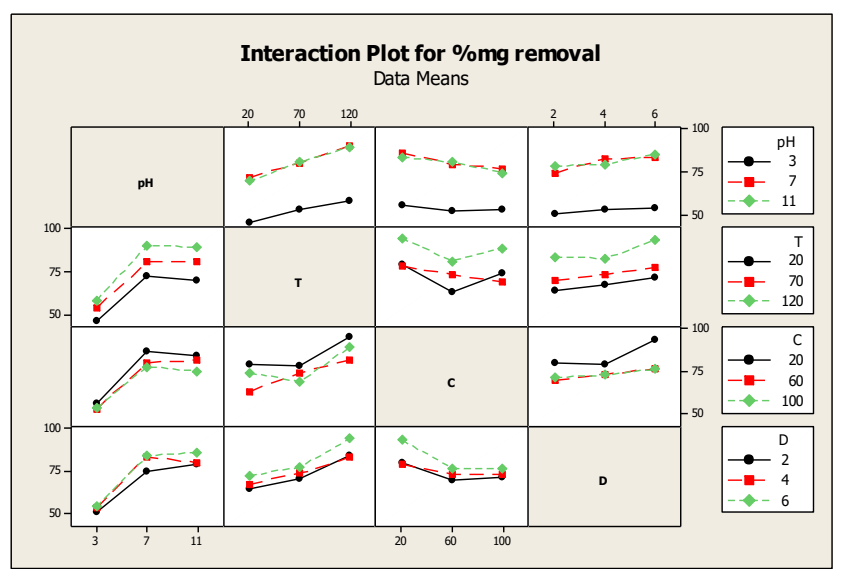

Figure 6. The interaction effects of the main factors affecting MG adsorption

\subsection{Optimization and model validation}

The main aim of optimization is to determine the optimum values of independent variables. In this software, the optimization of independent variables is done in three methods: graphical, numerical, and point prediction. In this research, the numerical optimization method was used. To optimize, the dosage of modified barley straw at the 
minimum level, MG concentration at the maximum level, $\mathrm{pH}$ in the range, and for contact time in the range were set for maximum desirability. Optimized variables are shown in Figure 7. The best local maximum was found to be at the $\mathrm{pH}$ 9.54, initial MG concentration of $20 \mathrm{mg} \mathrm{L}^{-1}$, modified barley straw dosage of $6 \mathrm{~g} \mathrm{~L}^{-1}$, and contact time of $120 \mathrm{~min}$. For comparison, MG removal efficiency using several other adsorbents are presented in Table 5. As can be seen, MG removal efficiency by modified barley Straw is almost higher than other studies.

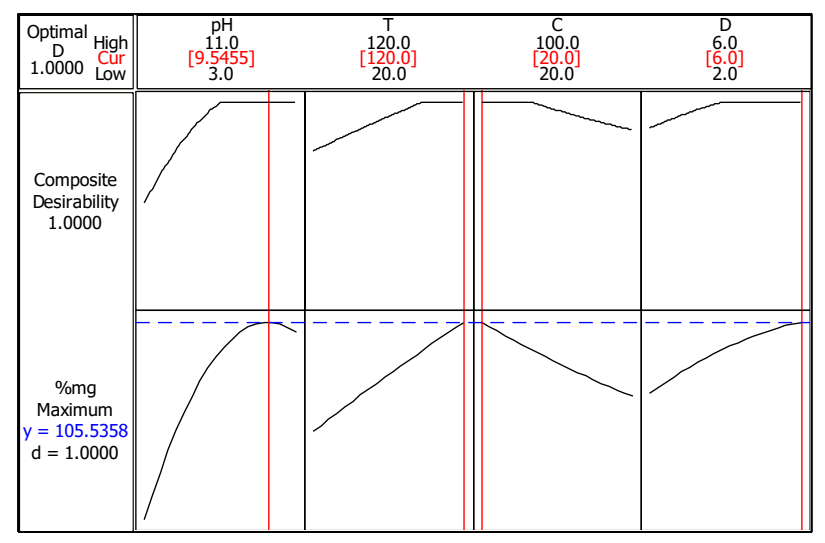

\subsection{Adsorption isotherms and kinetics}

The evaluation of reaction kinetics is essential in order to determine the factors affecting the reaction rate. To better understand the MG adsorption mechanism on Modified Barley Straw, kinetics models were calculated. The study of the different kinetics to forecast the adsorption rate is beneficial for design and modelling a process (Zhao et al., 2014). To compute the reaction kinetics of malachite green (MG) adsorption, pseudo-first order, pseudo-secondorder, intraparticle diffusion, and Elovich were used. Figure 8 presents the kinetics's models of pseudo-first-order (a), pseudo-second-order (b), intraparticle diffusion (c), and Elovich (d). Table 6 presents the calculated kinetic models and

kinetic constants for malachite green adsorption. As can be showed in Table 6, the coefficient of determination $\left(R^{2}\right)$ for the pseudo-second-order was greater than the others $\left(R^{2}=0.9926\right)$. As a result, the $M G$ adsorption on Modified Barley Straw could be well represented by the kinetic model of pseudo-second-order. In this model assumes which or chemisorption or chemical adsorption may be the controlling phase of the reaction rate in the adsorption process (Salleh et al., 2011).

Figure 7. Optimized variables for MG adsorption onto modified barley straw

Table 5. Comparison of the removal efficiency of MG by RSM

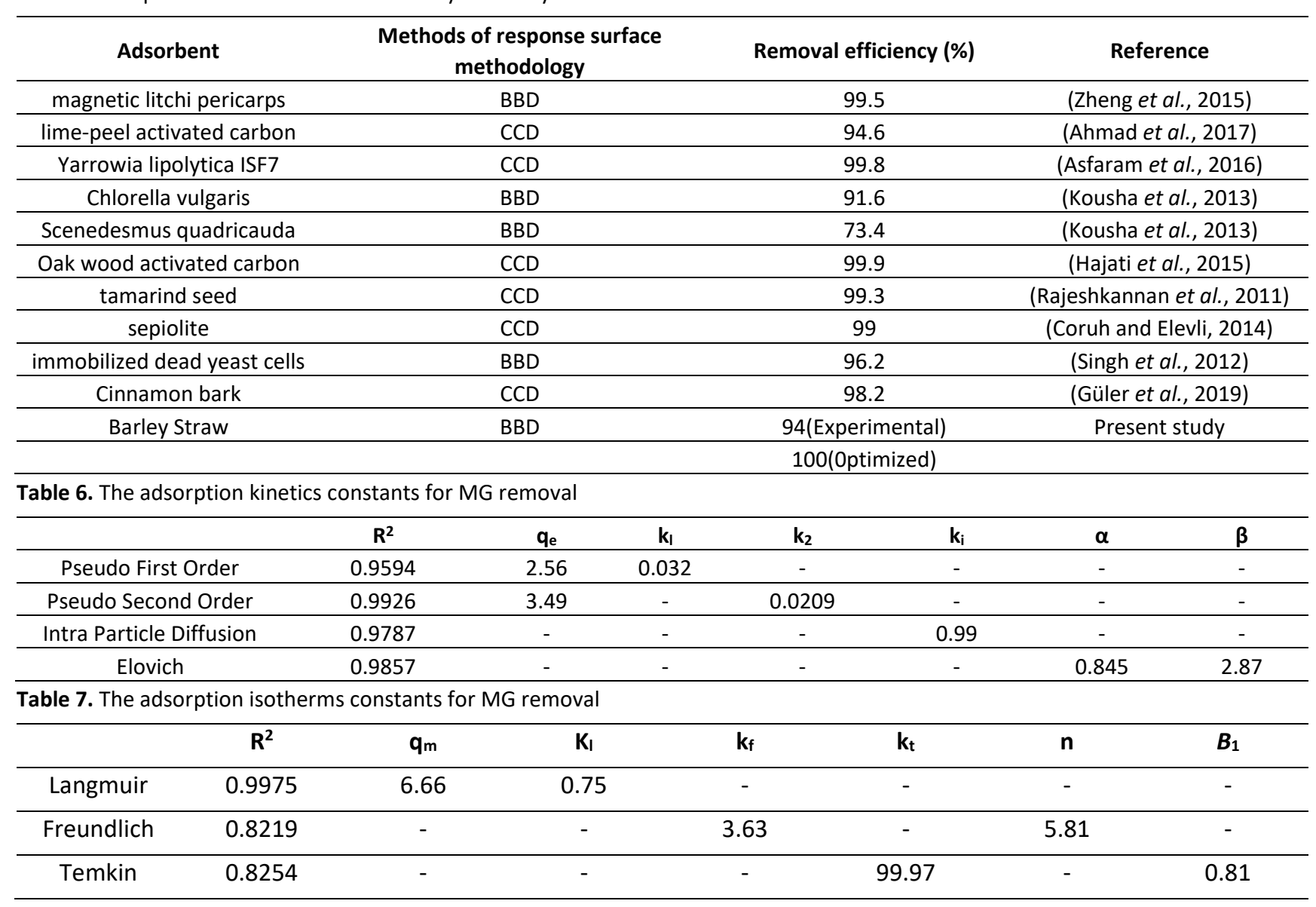

The adsorption isotherms were investigated in order to predict the adsorption capacity of Modified Barley Straw to MG as well as its adsorption mechanisms. The MG adsorption isotherms on Modified Barley Straw were studied by changing the initial MG concentration in the range of $1-100 \mathrm{mg} \mathrm{L}^{-1}$. To study the experimental data of 
MG adsorption, the isotherms models Langmuir, Freundlich, and Temkin were investigated. Figure 9 presents isotherm models Langmuir (a), Freundlich (b), and Temkin (c). Table 7 presents the calculated isotherms models and kinetic constants for MG adsorption. As can be showed in Table 7, the coefficient of determination ( $R$ squared or $R^{2}$ ) for the Langmuir was greater than Freundlich and Temkin $\left(R^{2}=0.9975\right)$. As a result, the MG adsorption on Modified Barley Straw could be well represented by the isotherm model of Langmuir. The model (Langmuir isotherm) define monolayer adsorption of a pollutant onto an absorbent (Ghasemi et al., 2015). Based on the Langmuir isotherm model, the maximum capacity of MG adsorption onto Modified Barley Straw was $6.66 \mathrm{mg} \mathrm{g}^{-1}$.
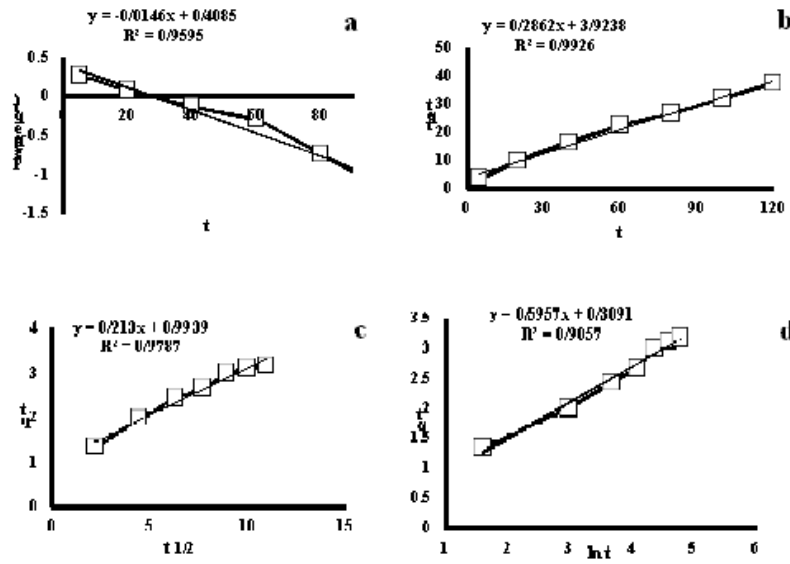

Figure 8. The kinetics's models (a: pseudo-first-order b: pseudosecond-order c: Intra particle diffusion d: Elovich)
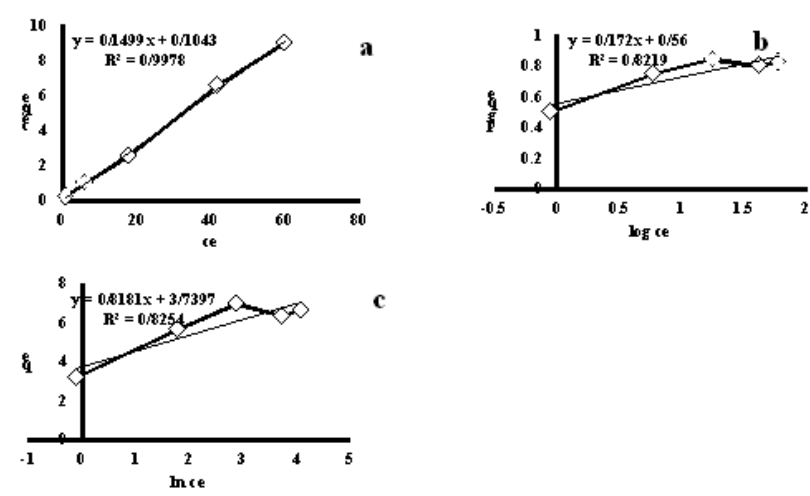

Figure 9. Isotherm models: a) Langmuir, b) Freundlich, and c) Temkin

\section{Conclusion}

In this research, straw was modified with citric acid according to previous studies. The Box-Behnken design was applied for the modelling and the optimization of MG adsorption. The development of mathematical model and optimization for removal of MG using statistical design of experiments appears to be a useful tool for prediction and understanding of interaction effects between process variables using BBD. The optimization modelling suggested the optimum values of the selected four independent process variables as the initial MG concentration $20 \mathrm{mg} \mathrm{l}^{-1}$, contact time $120 \mathrm{~min}$, initial solution $\mathrm{pH} 9.54$, and the adsorbent dose $6 \mathrm{~g} \mathrm{I}^{-1}$, to achieve the maximum reduction of the MG. So, the experimental results showed that under optimized conditions, modified barley straw can be used as an adsorbent for the adsorption of MG in aqueous solutions.

\section{References}

Ahmad M.A., Afandi N.S. and Bello O.S. (2017), Optimization of process variables by response surface methodology for malachite green dye removal using lime peel activated carbon, Applied Water Science, 7, 717-727.

Ahmad R. (2009), Studies on adsorption of crystal violet dye from aqueous solution onto coniferous pinus bark powder (CPBP), Journal of Hazardous Materials, 171, 767-773.

Akar S.T., Ozcan S., Akar T., Ozcan A. and Kaynak Z. (2009), Biosorption of a reactive textile dye from aqueous solutions utilizing an agro-waste, Desalination, 249, 757-761.

Asfaram A., Ghaedi M., Ghezelbash G.R., Dil E.A., Tyagi I., Agarwal S. and Gupta V.K. (2016), Biosorption of malachite green by novel biosorbent Yarrowia lipolytica isf: application of response surface methodology, Journal of Molecular Liquids, 214, 249-258.

Banerjee S., Sharma G.C., Gautam R.K., Chattopadhyaya M., Upadhyay S.N. and Sharma Y.C. (2016), Removal of Malachite Green, a hazardous dye from aqueous solutions using Avena sativa (oat) hull as a potential adsorbent, Journal of Molecular Liquids, 213, 162-172.

Belala Z., Jeguirim M., Belhachemi M., Addoun F. and Trouvé G. (2011), Biosorption of basic dye from aqueous solutions by Date Stones and Palm-Trees Waste: Kinetic, equilibrium and thermodynamic studies, Desalination, 271, 80-87.

Chakraborty S., Chowdhury S. and Saha P.D. (2011), Adsorption of crystal violet from aqueous solution onto $\mathrm{NaOH}$-modified rice husk, Carbohydrate Polymers, 86, 1533-1541.

Chakraborty S., Chowdhury S. and Saha P.D. (2013), Artificial neural network (ANN) modeling of dynamic adsorption of crystal violet from aqueous solution using citric-acid-modified rice (Oryza sativa) straw as adsorbent, Clean Technologies and Environmental Policy, 15, 255-264.

Chowdhury S., Mishra R., Saha P. and Kushwaha P. (2011), Adsorption thermodynamics, kinetics and isosteric heat of adsorption of malachite green onto chemically modi fi ed rice husk, Desalniation, 265, 159-168.

Coruh S. and Elevli S. (2014), Optimization of malachite green dye removal by sepiolite clay using a central composite design, Global Nest Journal, 16, 339-347.

Demirbas A. (2008), Heavy metal adsorption onto agro-based waste materials: A review, Journal of Hazardous Materials, 157, 220-229.

Demirbas A. (2009), Agricultural based activated carbons for the removal of dyes from aqueous solutions: A review, Journal of Hazardous Materials, 167, 1-9.

Deniz F. and Karaman S. (2011), Removal of Basic Red 46 dye from aqueous solution by pine tree leaves, Chemical Engineering Journal, 170, 67-74. 
El-Sayed G.O. (2011), Removal of methylene blue and crystal violet from aqueous solutions by palm kernel fi ber, Desalination, 272, 225-232.

Ghaderpoori M. and Dehghani M.H. (2016), Investigating the removal of linear alkyl benzene sulfonate from aqueous solution by ultraviolet irradiation and hydrogen peroxide process, Desalination and Water Treatment, 57, 1520815212.

Ghasemi S.M., Asgharnia H.A., Karimyan K and Adabi sh.(2015), Adsorption of Basic Blue3 (BB3) dye from aqueous solution by tartaric acid modified sunflower stem: Kinetics and Equilibrium studies, International Research Journal of Applied and Basic Sciences, 9, 686-694.

Ghasemi S.M., Ghaffari H., Sharafi K., Amoei A and Karimyan K.(2016), Removal of cd(II)ions from aqueous solutions onto modified sesame husk, Nature Environment and Polution Technology, 15,841-846.

Ghasemi S.M., Mohseni-Bandpei A., Ghaderpoori M., Keramati H., Taghavi M., Moradi M and Karimyan K.(2017), Aplication of modified maize hull for removal of $\mathrm{cu}(\mathrm{II})$ ions from aqueous solutions, Environment Protection Engineering , 43,93-103.

Golmohammadi S., Ahmadpour M., Mohammadi A., Alinejad A., Mirzaei N., Ghaderpoori M. and Ghaderpoori A. (2016), Removal of blue cat 41 dye from aqueous solutions with $\mathrm{ZnO}$ nanoparticles in combination with US and US- $\mathrm{H}_{2} \mathrm{O}_{2}$ advanced oxidation processes, Environmental Health Engineering and Management Journal, 3, 107-113.

Gong R., Liu Y., Jiang Y. and Li C. (2009), Isothermal, kinetic and thermodynamic studies on basic dye sorption onto tartaric acid esterified wheat straw, African Journal of Biotechnology, 8, 7138-7147.

Gözmen B., Turabik M. and Hesenov A. (2009), Photocatalytic degradation of Basic Red 46 and Basic Yellow 28 in single and binary mixture by UV/TiO 2 /periodate system, Journal of Hazardous Materials, 164, 1487-1495.

Güler M., Çetintaş S. and Bingöl D. (2019), Cinnamon bark as lowcost and eco-friendly adsorbent for the removal of indigo carmine and malachite green dyestuffs, International Journal of Environmental Analytical Chemistry, 99,1-23.

Gupta V.K. and Suhas (2009), Application of low-cost adsorbents for dye removal - A review, Journal of Environmental Management, 90, 2313-2342.

Hajati S., Ghaedi M. and Yaghoubi S. (2015), Local, cheep and nontoxic activated carbon as efficient adsorbent for the simultaneous removal of cadmium ions and malachite green: Optimization by surface response methodology, Journal of Industrial and Engineering Chemistry, 21, 760-767.

Han R., Zhang L., Song C., Zhang M., Zhu H. and Zhang L. (2010), Characterization of modified wheat straw, kinetic and equilibrium study about copper ion and methylene blue adsorption in batch mode,Carbohydrate Polymers,79, 1140-1149.

Jiang F., Dinh D.M. and Hsieh Y.-L. (2017), Adsorption and desorption of cationic malachite green dye on cellulose nanofibril aerogels, Carbohydrate Polymers, 173, 286-294.

Joglekar A.M. and May A.T. (1987), Product excellence through design of experiments. Cereal Foods World, 32857-868.

Kamarehie B., Jafari A., Ghaderpoori M., Amin Karami M., Mousavi K. and Ghaderpoury A. (2018), Catalytic ozonation process using $\mathrm{PAC} / \mathrm{Y}-\mathrm{Fe}_{2} \mathrm{O}_{3}$ to Alizarin Red $\mathrm{S}$ degradation from aqueous solutions: a batch study, Chemical Engineering Communications, 206, 898-908.
Karim A.B., Mounir B., Hachkar M., Bakasse M. and Yaacoubi A. (2009), Removal of Basic Red 46 dye from aqueous solution by adsorption onto Moroccan clay, Journal of Hazardous Materials, 168, 304-309.

Kousha M., Farhadian O., Dorafshan S., Soofiani N.M. and Bhatnagar A. (2013), Optimization of malachite green biosorption by green microalgae-Scenedesmus quadricauda and Chlorella vulgaris: application of response surface methodology, Journal of the Taiwan Institute of Chemical Engineers, 44, 291-294.

Massoudinejad M., Ghaderpoori M. and Rezazadeh M. (2015), The Removal of COD and Color from Textile Industry by Chlorine Hypochlorite, International Journal of Advanced Science and Technology, 76, 35-42.

Massoudinejad M., Ghaderpoori M., Shahsavani A. and Amini M.M. (2016), Adsorption of fluoride over a metal organic framework Uio-66 functionalized with amine groups and optimization with response surface methodology, Journal of Molecular Liquids, 221, 279-286.

Mohsenibandpei A., Alinejad A., Bahrami H. and Ghaderpoori M. (2016), Water Solution Polishing Of Nitrate Using Potassium Permanganate Modified Zeolite: Parametric Experiments, Kinetics And Equilibrium Analysis, Global Nest Journal, 18, 546-558.

Noroozi B., Sorial G.A., Bahrami H. and Arami M. (2007), Equilibrium and kinetic adsorption study of a cationic dye by a natural adsorbent-Silkworm pupa, Journal of Hazardous Materials, B139 167-174.

Olmez T. (2009), The optimization of $\mathrm{Cr}(\mathrm{VI})$ reduction and removal by electrocoagulation using response surface methodology, Journal of Hazardous Materials, 162, 1371-1378.

Rafatullah M., Sulaiman O., Hashim R. and Ahmad A. (2010), Adsorption of methylene blue on low-cost adsorbents: A review, Journal of Hazardous Materials, 177, 70-80.

Rajeshkannan R., Rajasimman M. and Rajamohan N. (2011), Decolourization of malachite green using tamarind seed: optimization, isotherm and kinetic studies, Chemical Industry and Chemical Engineering Quarterly/CICEQ, 17, 67-79.

Safronov V., Strelov V., Krivonogova N., Velikotskaya I., Khvostova A. and Bocharova M. (2012), Sol-gel films with immobilized acid-base indicators, Journal of Surface Investigation. X-ray, Synchrotron and Neutron Techniques, 6, 985-989.

Saha P., Chowdhury S., Gupta S., Kumar I. and Kumar R. (2010), Assessment on the Removal of Malachite Green Using Tamarind Fruit Shell as Biosorbent, CLEAN - Soil, Air, Water, 38, 437-445.

Saleh H.N., Dehghani M.H., Nabizadeh R., Mahvi A.H., Hossein F., Ghaderpoori M., Yousefi M. and Mohammadi A. (2018), Data on the acid black 1 dye adsorbtion from aqueous solutions by low-cost adsorbent-Cerastoderma lamarcki shell collected from the northern coast of Caspian Sea, Data in Brief, 17, 774780.

Salleh M.A.M., Mahmoud D.K., Karim W.A.W.A. and Idris A. (2011). Cationic and anionic dye adsorption by agricultural solid wastes:A comprehensive review, Desalination, 280, 113.

Sharma N., Tiwari D.P. and Singh S.K. (2012), Decolourisation of Synthetic Dyes by Agricultural Waste-A Review, International Journal of Scientific \& Engineering Research, 3, 1-10.

Sharma P., Kaur H., Sharma M. and Sahore V. (2011), A review on applicability of naturally available adsorbents for the removal 
of hazardous dyes from aqueous waste, Environmental Monitoring and Assessment, 183, 151-195.

Shen L., Wu W., Ruowen Liang, Rui Lin and Wu L. (2013), Highly dispersed palladium nanoparticles anchored on UiO$66(\mathrm{NH} 2)$ metal-organic framework as a reusable and dual functional visible-lightdriven photocatalyst, The Royal Society of Chemistry, 5.19, 9374-9382.

Simsek E.B., Özdemir E. and Beker U. (2013), Process Optimization for Arsenic Adsorption onto Natural Zeolite Incorporating Metal Oxides by Response Surface Methodology, Water, Air, \& Soil Pollution, 224, 1614-1628.

Singh A., Rani S. and Bishnoi N.R. (2012), Malachite green dye decolorization on immobilized dead yeast cells employing sequential design of experiments, Ecological Engineering, 47, 291-296.

Singh K.K., Rastogi R. and Hasan S.H. (2005), Removal of cadmium from wastewater using agricultural waste 'rice polish', Journal of Hazardous Materials, A121, 51-58.

Tilaki R.A.D., Balarak D. and Ghasemi M. (2014), Study Survey of Efficiency Agricultural Weast in Removal of Acid Orang 7(AO7) Dyes from Aqueous Solution: Kinetic and Equilibrium Study, Iranian Journal of Health Sciences, 2, 51-61.

Wong K.K., Lee C.K., Low K.S. and Haron M.J. (2003), Removal of $\mathrm{Cu}$ and $\mathrm{Pb}$ by tartaric acid modified rice husk from aqueous solutions, Chemosphere, 50, 23-28.

Yang J.-S., Park Y.-T., Baek K. and Choi J. (2010), Removal of metal ions from aqueous solutions using sawdust modified with citric acid or tartaric acid, Separation Science and Technology, 45, 1963-1974.

Zainal S., Nadzirah K.Z., Noriham A. and Normah I. (2013), Optimisation of beef tenderisation treated with bromelain using response surface methodology (RSM), Agricultural Sciences, 4, 65-72.

Zhao X., Fang X., Wu B., Zheng L. and Zheng N. (2014), Facile synthesis of size-tunable ZIF-8 nanocrystals using reverse micelles as nanoreactors, Science China Chemistry, 57, 141146.

Zheng H., Qi J., Jiang R., Gao Y. and Li X. (2015), Adsorption of malachite green by magnetic litchi pericarps: a response surface methodology investigation, Journal of Environmental Management, 162, 232-239.

Zhu B., Fan T. and Zhang D. (2008), Adsorption of copper ions from aqueous solution by citric acid modified soybean straw, Journal of Hazardous Materials, 153, 300-308.

Zolgharnein J., Shahmoradi A. and Ghasemi J.B. (2013), Comparative study of Box-Behnken, central composite, and Doehlert matrix for multivariate optimization of $\mathrm{Pb}$ (II) adsorption onto Robinia tree leaves, Journal of Chemometrics, 27, 12-20. 